\title{
Nurses' perception regarding utilization of information technology at primary health care centers in Port Said city
}

\section{Rasha Mohammed Mohammed ${ }^{1}$, Reda Ibrahim Elmouafy ${ }^{2}$, Magda Aly Mohammed ${ }^{3}$, Ateya Megahed Megahed Ibrahim ${ }^{4}$}

Clinical Instructor ${ }^{1}$, Assistant Professor of Family and Community Health Nursing, Faculty of Nursing, Port Said University ${ }^{2,3}$, Lecturer of family \& Community health nursing Faculty of Nursing port said university ${ }^{4}$

\begin{abstract}
Background: Technological development and adoption of new technology in healthcare have greatly affected the work of nurses, as increased use of technology has created a constant demand for nurses to develop new skills and competencies, otherwise technology is expected to improve the quality of care and ease the work of nurses at healthcare organizations. Aim: This study aimed to assess nurses` perception regarding the utilization of information technology at primary health care centers in Port Said City. Subjects and Methods: A descriptive research design was used for this study. Setting: This study was conducted at the primary health centers chosen randomly from five districts affiliated to Port Said City. Subjects: All nurses working in the five primary health care centers (95 nurses) were included in the study. Tools: Data were collected using two tools. Tool 1: Self-administered nursing informatics perception questionnaire. Tool 2: Assessment nurses' barriers questionnaire. Results: The study revealed that most of the studied nurses $(80.4 \%)$ had negative perception regarding of using information technology, In addition, most of the studied nurses faced with multiple personal and administrative barriers. Conclusion: the study concluded that most of the studied nurses had negative perception regarding aspects of using information technology and most of the studied nurses faced with multiple personal and administrative barriers. Recommendations: providing periodic effective training programs for nurses regarding using of information technology in primary care centers.
\end{abstract}

Key words: Nurses' perception, information technology. 


\section{INTRODUCTION}

Information technology has the potential to improve the health of individuals and the performance of providers, yielding improved quality, cost savings, and greater engagement by patients in their own health care. Information technology has had a significant impact on all aspects of the society in the $21^{\text {st }}$ century. Information technologies embody all digital technologies that support the electronic capture, storage, processing, and exchange of information in order to promote health, prevent illness, treat disease, manage chronic illness, and so on (Chan ,2019).

Information technology increasingly important aspect in healthcare organizations especially primary health care, therefore, its application in health professional education, research and clinical practice are critical issue. NursingInformatics defined by Abdrbo (2015), as the involvement of information technology in different nursing practices, including clinical nursing, management, research or education and their management, with information technologies to promote the health of people, families and communities worldwide" (Buabbas, Al-Shawaf, \& Almajran, 2016).

The electronic health record (HER) adoption in Egypt has fallen away from the desired, just few centers apply the system and a lot of nurses in the medical sector are unaware of what system and what are its benefits. It shown that the proportion of health care centers that have implemented the system was too small, and the development of the system in Egypt is less than 7\% approximately, which requires to be applied more in all centers, It Still a long way to go in realizing a fully integrated efficient e-health system, but there is an undeniable hope that it has started on the long tedious journey towards e- health system (Saad, 2014).

Health care is a good example of those which are influenced by information technology. Health information technology (HIT) has significantly affected health care in many numerous views. They have increased efficiency in communication of information for healthcare team members as well as patients (Christiansen, 2017). Technology is advancing quickly and while it has the ability to improve healthcare outcomes, it has additionally affected patient and nurse relationships (Jenni, Otto \& 
Olli, 2019). Information technology continues to rapidly advance and is incorporated in essentially all health care professional and research fields including nursing. It is significant that nurses acquire competences to effectively utilize information technology in their slandered practice to profit patients and increase more fulfillment from their work (Friganovic, Jelec \&Sukalic, 2017).

Healthcare is portrayed by the complexity and furthermore by abroad ranges of various actors as service receivers, services providers, and health insurance agencies (Hussain, 2019). Patients gets services which are given by various individuals and institutions and incorporate health care professionals, hospitals, outpatient care services, rehabilitation services, and drug stores (Shin, Cummings \& Ford, 2018).

Barriers use of the primary health care are factors known to reduce the quality of the clinical placement experience. Barriers include occupational stress; psychological stressors such as high workload, problematic working relationship, lack of supervisors' support and low level of recognition and reward are all too commonly reported in health service delivery environments. These induce states of anxiety, inhibit learning, and impair performance and compromise health and wellbeing (Buabbas, Al-Shawaf, \& Almajran, 2016).

Nurses play a key role in primary health care Corporation. They are the first point of contact for patients entering health centers, and they make up the largest component of the workforce (Kleib, \& Olson, 2015). Nursing being an essential part of the health care delivery system which presented ceaselessly to a quick of changes (Ellis, 2015). The uses of computer technology proceeds to fast progress in our general public, nurses are being challenged to consolidate the utilization of computers in to their every day schedule of giving patient care. Even through nurses have utilized computers for a long time to put requests and look up testes results, they are hesitant to give up the traditional means of charting and adopt electronic documentation framework (Abdul Salam, Elsegaey \& Khraif, 2015). However, nursing informatics, has great benefits such as, record keeping, enhancing communication, perform simple calculations, support decision making, facilitates gaining competitive advantage, better management of chronic diseases, faster retrieval of record, improving process flow and productivity (Kaye, 2017). 


\section{Significance of this study}

In recent years, there have been significant changes and developments in the health professions, especially nursing, with the development of technology. The use of computers in nursing has increased in the 1970s due to the need for nurses to document information and services they provide. In these years, computers have been used effectively in diagnosing, treating, planning, implementing, evaluating and keeping records of healthy/sick person's problems. Health care system is the wider umbrella that must contain every citizen to be involved in E-health, which need integration between the health sector and IT sector for enhancing more interactive and accurate system that can help in future development of health care services provided in primary health care centers (Jelec, et al., 2016). Hence, the nurse is considered the safe guarding line in providing healthcare services in primary health care centers, and by the updated electronic evolution in health care systems and telenursing, all nurses must be awkward with this technological advancement to save time, efforts, costs, and medical and administrative record errors.

Several organizations such as American nurse association (ANA) at the year 2010, recommended all nurses to have competencies in information technology (IT). Although adoption of health care informatics still faces significant barriers, the acceptance and perception of medical staff particularly nurses remain at the main significant obstacles to activate IT in healthcare organizations. It was: lack of patient unique identifier, lack of funds, lack of computer (Liukko, \& Perttula, 2017). The study clearly demonstrated that the current status of Electronic Health Record (HER) adoption in Egypt has fallen away from the desired and the development of the system in Egypt is less than 7\% approximately, which requires to be applied more in all centers. It stills a long way to go in realizing a fully integrated efficient e-health system, but there is an undeniable hope that it has started on the long tedious journey towards e-health system. So, this study aimed to assess nurses` perception regarding the utilization of information technology at primary health care centers in Port Said City.

\section{AIM OF STUDY:}

The aim of this study was to assess nurses ' perception regarding the utilization of information technology at primary health care centers in Port Said City. 


\section{Research question:}

What are the nurses 'perception regarding the utilization of information technology at primary health care centers?

\section{Research Design:}

A descriptive cross-sectional research design was used in this study.

\section{Study Setting:}

This study was conducted at the primary health care centers located at Port Said City. Port Said City is divided into five districts and they were namely; Elganoub district which consist of: Elraswa unit, Alhazaer unit, Elsedk unit, Alkab unit, Alradwan unit, Omkhalaf unit, Alasher unit, Bahr elbaker unit, Elreka unit, Elsalam unit, Suzan Mubarak unit, Hod-Badran unit. Elzhour district which consist of: Omar Ibnelkhatab center, Osman Ibnafan center, Elgawhara center. El-dawahy district which consist of: Bank Alaskan center, Alkaboty center, Fatima Elzahraa center, Mustafa Kamel center. Al Arab district which consist of: Elarab care unit, Elarab center. Elmanakh district which consist of: El-manakh center, Elmanakh care child unit, Elkewate unit.

\section{SUBJECTS:}

A purposive sample of this research consists of all nurses $(n=95)$ working in primary health care centers located at Port Said City.

\section{Sampling technique:}

By applying cluster sample technique, Port Said City divided in to five districts as mentioned above and simple random sample was used to choose one primary health care centers from each district. Namely: El-kab health care center from El-Ganoub district and consist of 11 nurses, Osman Ibnafan from El-zohour district and consist of 22 nurses, Bank El-eskan from El- Dawahy district and consist of 19 nurses, El-Arab health care center from Al-Arab district and consist of 16 nurses, and El-mankhah health care center from El-mankhah district and consist of 27 nurses.

Tools of data collection: Data of this study was collected by using the following two tools:

Tool I: Self-administered nursing informatics perception questionnaire, developed by the researcher into simple Arabic language based on the related literature review (Noh et al., 2012, Woreta, Kebede \& Zegeye 2013) it consists of two parts:

The first part: it was concerned with personnel characteristics of nurses such as; age, gender, family numbers, level of education, and years of work. 
The second part: Structured sheet to assess nurses' perception regarding the using of information technology and consisted of 22 statements which divided into 11 statements concerned with positive aspects and 11 statements concerned with negative aspects regarding the uses of information technology.

\section{Scoring system}

The scoring system was done as follows, Responses of the nurses were scored throughout the entire questionnaire as follows: disagree $=$ Zero, uncertain $=1$ and agree $=2$ The score obtained for each question was summed to get the total score for the nurses' perception.

Tool II: Assessment nurses' barriers questionnaire; it was adapted from (Breimaier, Halfens, and Lohrmann, 2011), it was translated into simple Arabic language and modified by the researcher to assess barriers facing nurses in using computer at work. It consisted of 10 statements divided to two major categories: administrative and personal barriers.

\section{Scoring system}

Scoring system calculated as follow: Responses to each of the 10 items are rated on a three-point Likert scale from never (one) to always (three). The score obtained for each item was summed to get the total score for it. The total score is converted into a percent score, and means and standard deviations were computed. If the barriers which face nurses in using computer are less than $30 \%$ it considered slightly limited. If the barriers which faces nurses in using computer is $30 \%$ or more it considered limited to some extended and extremely limited.

\section{Validity and reliability}

After the translation of the questionnaires to Arabic, content validity of the questionnaires was confirmed by a panel of five academic experts in family and community health nursing specialty, the recommendations delivered little modifications that were made. Reliability test was calculated using Cranach's alpha, the result showed that tool (1) internal consistency $=0.75$, which indicating fair reliabilityy, where the tool (11) Cranach's alpha coefficient equal 0.95, which indicate high reliability.

\section{Preparatory phase:}

It includes reviewing of literature, different studies and theoretical knowledge of various aspects of the study using books, research articles, internet, periodicals and magazines to develop tools for data collection. Review the official website as pub med, Cochrane library, Ebesco and so on. 


\section{Pilot study:}

A pilot study was done on $10 \%$ (10 nurses) subjects to test clarity, applicability, understanding of language, and time needed for completing the tool. Few items were modified according to participants' responses in the pilot study. The subjects included in the pilot study were excluded from the total study sample. This phase was carried out in a period of two weeks.

\section{Field work:}

The data were collected from nurses by the researcher after obtaining an official agreement from the directors of primary health care centers at Port Said City, this step take one week. The data have been collected over a period of 3 months. The actual field of work carried out from beginning of October (2019) to the beginning of December (2019). Meeting with the nurses was conducted on an individual basis to explain the aim of the study and to gain their cooperation. The questionnaire sheet was filled in by nurses while they were on duty in the morning shifts. Each sheet lasted 2030 minutes to be filled. Five days a week from Saturday to Thursday at morning shift from 8:00 Am to 2:00 Pm and nurses were recruited conveniently. Data were categorized by researcher checked and revised at January, 2020 and then data were statistical analyzed at the beginning of February, 2020 to the beginning of April, 2020. The present study consumed about 6 months. One month of them for obtaining the official permission, pilot study and test clarity and feasibility of tool. The next two months consumed for data collection while, one month for data entry and Two months for statistical analysis.

\section{Administrative Design:}

A formal letter was issued from dean of faculty of nursing in Port Said University. Then the study was approved by the directorate of primary health care centers. At the time of data collection a verbal agreement is taken from every participant in the study after clear and proper explanation of the study purpose and its importance for them.

\section{Ethical considerations:}

An approval was taken from research ethical committee of faculty of nursing, Port Said University. Moreover, an approval was taken from primary health care centers directors to participate in the study after explanation the study aim. And then an oral consent for participation in the study was obtained from each one of them, after explanation of the study aim and detail data collection process to be familiar with the importance of his /her participation. In addition, a brief and comprehensive explanation of the study will be given to assured nurses that the information obtained was confidential and used only the purpose of the study. The studied participants (nurses) were informed that their participation is voluntary \& they have the right withdraw from study at any time without rationalization. Additionally, all data collected from the studied subjects was processed in a total confidentiality and the names of the respondents were not required in order to ensure anonymity. Moreover, the process of data collection not disturbs the harmony of the work of the abovementioned setting. 


\section{Statistical analysis:}

Data entry and statistical analysis were done using SPSS 23.0 statistical software package. Descriptive statistics included frequencies and percentages for qualitative variables, and means and standard deviations for quantitative variables, one's descriptive statistics and frequencies were run to examine normality and determine if any skewness or kurtosis occurred. Parametric and non-parametric inferential statistics as (paired t-test, two related sample test and Chi-square test) were used. For all of the statistical tests done, the threshold of significance was fixed at the 5\% level (P-value).

\section{RESULTS:}

The personal characteristics of the studied nurses clarified in Table (1): It can be seen that the nurses' ages ranged from 20 to more than 50 years with a mean age and S.D $32 \pm 7.22$ years old. About $85.3 \%$ were female, $54.7 \%$ had a diploma degree and $42.1 \%$ were held a bachelor degree. And $68.4 \%$ of them reported that they had enough income. $50.5 \%$ of the respondents have worked in a health center for less than 10 years.

Table (2): represents the distribution of nurses' perception regarding the positive aspects of using information technology, it was explored that the highest areas which the studied nurses were agreed regarding positive aspects of using information technology were using computer produce easy completion of nursing duties with less effort and work load, IT contributes to medical research, using technological devises improving peoples 'view about the professional role of nurses and Improve of nurses knowledge and skills that allow a higher competence of nurses $84.2 \%, 83.2 \%, 80.0 \%$ and $78.9 \%$ respectively .

Table (3): shows the distribution of nurses' perception regarding the negative aspects of using information technology. It was seen that the highest areas which the studied nurses were agreed regarding negative aspects of using information technology were IT requires high and more qualified skills, Must be taken a vacation regularly from center pressure technology, Restrict autonomy of nurses in making decision by increasing dependence on other health care professionals, and People responsible for the growth of the EMR don't understand my problems $66.3,63.2 \%, 54.7$, and 53.7 respectively.

Table (4): Shows that $71 \%$ of the studied nurses reported never regarding the item "The internet data is incorrect ", and $74.7 \%$ of the studied nurses reported sometimes in the same point, while $37.9 \%$ confirmed that not having enough computers was the most administrative barriers for using computer in clinical nursing practice. Furthermore, the results emphasized that, $58.9 \%$ of the studied nurses confirmed that presence of administrative barriers for using computer in clinical nursing practice in sometimes cases. In relation to personal barriers, this table reveals that $64.2 \%$ of the 
studied nurses stated that they "never" I'm too old to use computer and $64.2 \%$ of them reported that they sometimes had a little knowledge of using IT, while $30.5 \%$ showed that lake of encouragement by management was always. The most relevant personal barriers for using computer in clinical nursing practice. Moreover, the results indicated that, $55.8 \%$ of the total scores studied nurses confirmed presence of personal barriers for using computer in clinical nursing practice in sometimes cases.

Table (5): as revealed in the table, there were no any statistically significant correlation between the studied nurses' personal characteristics with total positive and negative perception regarding to the using of informatics technology.

Table (1): Distribution of personal characteristics of the studied nurses $(n=95)$

\begin{tabular}{|c|c|c|}
\hline Items & $\mathbf{N}$ & $\%$ \\
\hline \multicolumn{3}{|l|}{ Age } \\
\hline $20<30$ & 40 & 42.1 \\
\hline $30<40$ & 43 & 45.3 \\
\hline $40<50$ & 9 & 9.5 \\
\hline$\geq 50$ & 3 & 3.1 \\
\hline Mean \pm SD & \multicolumn{2}{|c|}{$32 \pm 7.22$} \\
\hline \multicolumn{3}{|l|}{ Gender } \\
\hline Male & 14 & 14.7 \\
\hline Female & 81 & 85.3 \\
\hline \multicolumn{3}{|l|}{ Education } \\
\hline Diploma & 52 & 54.7 \\
\hline Bachelor & 40 & 42.1 \\
\hline Master & 3 & 3.2 \\
\hline \multicolumn{3}{|l|}{ Income } \\
\hline Enough & 65 & 68.4 \\
\hline Enough and more & 8 & 8.4 \\
\hline Not enough & 22 & 23.2 \\
\hline \multicolumn{3}{|c|}{ Year worked at PHCC } \\
\hline$<10$ & 48 & 50.5 \\
\hline $10<20$ & 32 & 33.7 \\
\hline$\geq 20$ & 15 & 15.8 \\
\hline Mean \pm SD & \multicolumn{2}{|c|}{$10.69 \pm 7.721$} \\
\hline
\end{tabular}


Table (2): Distribution of nurses' perception regarding the positive aspects of Using information technology $(n=95)$

\begin{tabular}{|l|c|c|c|c|c|c|}
\hline \multicolumn{1}{|c|}{ Items } & \multicolumn{3}{c|}{ Agree } & \multicolumn{2}{c|}{$\begin{array}{c}\text { Uncerta } \\
\text { in }\end{array}$} & \multicolumn{2}{c|}{ Disagree } \\
\cline { 2 - 7 } & $\mathbf{N}$ & $\mathbf{\%}$ & $\mathbf{N}$ & $\%$ & $\mathbf{N}$ & $\%$ \\
\hline $\begin{array}{l}\text { Produce easy completion of nursing duties through } \\
\text { performing nursing tasks with less nurse's fatigue and } \\
\text { work load. }\end{array}$ & 78 & 82.1 & 13 & 13.7 & 4 & 4.2 \\
\hline $\begin{array}{l}\text { Improve of nurse's knowledge and skills that allow } \\
\text { a higher competence of nurses }\end{array}$ & 75 & 78.9 & 14 & 14.7 & 6 & 6.3 \\
\hline $\begin{array}{l}\text { Increase prestige of nurses by improving of image and } \\
\text { opinions other peoples about the professional role of } \\
\text { nurses }\end{array}$ & 76 & 80.0 & 16 & 16.8 & 3 & 3.2 \\
\hline Enhance nurse cooperation with other of health team & 65 & 68.4 & 24 & 25.3 & 6 & 6.3 \\
\hline Help to compensate the shortage of nurses & 51 & 53.7 & 29 & 30.5 & 15 & 15.8 \\
\hline Technological devices are the eyes and hands of nurse & 50 & 52.6 & 27 & 28.4 & 18 & 18.9 \\
\hline IT contributes to medical research & 79 & 83.2 & 12 & 12.6 & 4 & 4.2 \\
\hline It is easy to learn how to use an EMR & 63 & 66.3 & 28 & 29.5 & 4 & 4.2 \\
\hline $\begin{array}{l}\text { The information I access from the EMR makes my } \\
\text { work easier. }\end{array}$ & 75 & 78.9 & 17 & 17.9 & 3 & 3.2 \\
\hline $\begin{array}{l}\text { I am certain about the reliability of the data } \\
\text { Documented }\end{array}$ & 64 & 67.4 & 30 & 31.6 & 1 & 1.1 \\
\hline Information is always updated & 55 & 57.9 & 37 & 38.9 & 3 & 3.2 \\
\hline
\end{tabular}

Table (3): Distribution of nurses ' perception regarding the negative aspects of using Information technology $(\mathrm{n}=95)$

\begin{tabular}{|c|c|c|c|c|c|c|}
\hline \multirow[t]{2}{*}{ Items } & \multicolumn{2}{|c|}{ Agree } & \multicolumn{2}{|c|}{ Uncertain } & \multicolumn{2}{|c|}{ Disagree } \\
\hline & $\mathbf{N}$ & $\%$ & $\mathbf{N}$ & $\%$ & $\mathbf{N}$ & $\%$ \\
\hline $\begin{array}{l}\text { Increase errors of health team personnel through } \\
\text { misinterpretation of data provided by machines }\end{array}$ & 49 & 51.6 & 34 & 35.8 & 12 & 12.6 \\
\hline Increase nurses psychological stress and burnout & 43 & 45.3 & 26 & 27.4 & 26 & 27.4 \\
\hline Health and physical risks for nurses & 37 & 38.9 & 33 & 34.7 & 25 & 26.3 \\
\hline $\begin{array}{l}\text { Must be taken a vacation regularly from center pressure } \\
\text { technology }\end{array}$ & 60 & 63.2 & 19 & 20.0 & 16 & 16.8 \\
\hline $\begin{array}{l}\text { Restrict autonomy of nurses in making decision by } \\
\text { increasing dependence on other health care professionals }\end{array}$ & 52 & 54.7 & 27 & 28.4 & 16 & 16.8 \\
\hline Time to loge on is to long & 39 & 41.1 & 27 & 28.4 & 29 & 30.5 \\
\hline Beneficiaries don't like the nurse to use computer & 31 & 32.6 & 43 & 45.3 & 21 & 22.1 \\
\hline It is difficult to deal with IT & 34 & 35.8 & 28 & 29.5 & 33 & 34.7 \\
\hline $\begin{array}{l}\text { People responsible for the growth of the EMR don't } \\
\text { understand my problems }\end{array}$ & 51 & 53.7 & 30 & 31.6 & 14 & 14.7 \\
\hline I don't find all the information I need & 48 & 50.5 & 28 & 29.5 & 19 & 20.0 \\
\hline IT requires high and more qualified skills & 63 & 66.3 & 19 & 20.0 & 13 & 13.7 \\
\hline
\end{tabular}


Table (4): Distribution of nurses according to their Administrative and personal barriers use of computer in clinical nursing practice $(n=95)$

\begin{tabular}{|c|c|c|c|c|c|c|}
\hline \multirow[t]{2}{*}{ Items } & \multicolumn{2}{|c|}{ Never } & \multicolumn{2}{|c|}{ Sometimes } & \multicolumn{2}{|c|}{ Always } \\
\hline & $\mathbf{N}$ & $\%$ & $\mathbf{N}$ & $\%$ & $\mathbf{N}$ & $\%$ \\
\hline \multicolumn{7}{|l|}{ Administrative barriers } \\
\hline Computers are not enough & 12 & 12.6 & 47 & 49.5 & 36 & 37.9 \\
\hline The internet data is incorrect & 12 & 2.63 & 70 & 73.6 & 13 & 13.68 \\
\hline Using the computer doesn't fillfy work requirement & 23 & 24.2 & 63 & 66.3 & 9 & 9.5 \\
\hline $\begin{array}{l}\text { More senior staff takes priority to use the } \\
\text { computer }\end{array}$ & 22 & 23.2 & 50 & 52.6 & 23 & 24.2 \\
\hline $\begin{array}{l}\text { Work time doesn't give me enough time to } \\
\text { use the computer }\end{array}$ & 26 & 27.4 & 50 & 52.6 & 19 & 20.0 \\
\hline \multicolumn{7}{|l|}{ Personal barriers } \\
\hline I have a little knowledge of using IT. & 23 & 24.2 & 61 & 64.2 & 11 & 11.6 \\
\hline I'm too old to use computer & 61 & 64.2 & 26 & 27.4 & 8 & 8.4 \\
\hline $\begin{array}{l}\text { I have little self confidence in using the } \\
\text { computer. }\end{array}$ & 29 & 30.5 & 50 & 52.6 & 16 & 16.8 \\
\hline Lake of encouragement by management. & 14 & 14.7 & 52 & 54.7 & 29 & 30.5 \\
\hline $\begin{array}{l}\text { The increasing the computer coast much } \\
\text { many. }\end{array}$ & 33 & 34.7 & 37 & 38.9 & 25 & 26.3 \\
\hline
\end{tabular}

Table (5): Correlation between personal characteristics, positive perception and negative perception regarding uses of information technology $(n=95)$

\begin{tabular}{|l|l|c|c|}
\hline \multicolumn{2}{|c|}{ Personal information } & Total positive perceptior & Total negative perception \\
\hline \multirow{2}{*}{ Age } & $\mathbf{r}$ & 0.088 & -0.156 \\
\cline { 2 - 4 } & P value & 0.836 & 0.648 \\
\hline \multirow{2}{*}{ Education } & $\mathbf{r}$ & 0.016 & -0.195 \\
& P value & 0.880 & 0.058 \\
\hline \multirow{2}{*}{ Income } & $\mathbf{P}$ & -0.057 & 0.188 \\
\hline \multirow{2}{*}{ Experience } & P value & 0.585 & 0.068 \\
& $\mathbf{r}$ & -0.095 & 0.169 \\
\hline & P value & 0.357 & 0.101 \\
\hline & P value & -0.057 & -0.010 \\
\hline
\end{tabular}

$*$ Correlation is significant at the 0.05 level (2-tailed). $\quad * *$ Correlation is significant at the 0.01 level (2-tailed).

\section{DISCUSSION:}

Health information technology (HIT) delivers a wide range of benefits in clinical nursing practice that reduces costs and increase productivity, better delivery of care, improves patient safety, more effective communication between providers, and increases access to information. The computer is an important tool in the 
management of information because of the speed with which it processes information. It is the major information technology tool that has transformed information and data handling processes in all endeavors (Naylor, 2015).

The growth of hospital information systems had significant impacts on nursing practice Integration of computers in the work performed by nurses is an innovation that requires nurses to change their working methods and even their function in the department. Nurses have turned their attention to the computer process, thus reducing the time lost unnecessarily with manual data registration, and allowing more contact with the patient, therefor, nurses must be equipped with appropriate instrument, that are capable of efficiently-managed data (Chan,2019).

So, the aim of this study was to assess nurse's perception regarding the utilization of information technology at primary health care centers in Port Said city. The findings of the current study clarify that most of the studied nurses had negative perception regarding positive aspects of using information technology, this result may be referred to the fact that there were an inverse statistical relationship between positive aspect of knowledge and benefits of information technology, while the relationship between negative aspects of IT gets significant in an elective direction, in addition less than one third of studied nurses use computer at work with nearly two thirds do not use computer at work any hours per week, more than half do not use computer any hours per week at home, more than half of nurses hadn't courses in basic component of computer, and more than half had sometimes both administrative and personal barriers regarding using of computer in clinical practice.

This result was in the same line with the study done by Christiansen, et al. 2017 which entitled "Nurses' Use and Perception of an Information and Communication Technologie System for improving, coordination during hospital discharges: showed that the majority of the studied group had negative perception regarding positive aspects of using information technology

This result was in contrast with other study entitled understanding the impact of nurses' perception and technological capability on nurses' satisfaction with nursing information system usage:,Taiwan, , indicated that the coalignment of nurses' 
perception of Nursing Information System (NIS) and the technological systems had a positive impact on nurses' satisfaction with net work information system usage(Lin, etal., 2016).

Also, Fajarini, Rahayu, and Setiawan, (2020) who conducted a study entitled "Factors related to doctors' and nurses' perceptions of evidence-based practice and healthcare information access through information and communication technology in Depok City", estimated that nurses had positive perception in terms of knowledge dissemination related to using of information technology.

The results of the current study revealed that three quarters of the studied nurses reported never regarding the item "The internet data is incorrect ", and three quarters of the studied nurses reported sometimes in the same point, while slightly more than one third confirmed not having enough computers was the most administrative barriers for using computer in clinical nursing practice. Furthermore, the results emphasized that, more than half of the studied nurses confirmed that presence of administrative barriers for using computer in clinical nursing practice in sometimes cases. Also, two thirds of the studied nurses stated that they never too old to use computer.

From the researcher point of view, this might be due to lack of encouragement by managers, lack of training learning computer skills, lack of available computers in centers. More senior staff takes priority to use the computers, and no enough time to use computer by other staff in addition to work overloads with shortage in nursing staff which hinder using of computers at workplaces.

This result is agreed with Irinoye (2018), who assessed barriers towards adopting computer and founded that there are many barriers as insufficient computer skills and lack of training. While these findings were not in accordance with Hasanain(2019), who implemented nurses' adoption of computer and found that the barriers towards using computer are inadequate capital for purchase, concern about maintenance coast, resistance on the part of physicians, and lack of availability of staff with adequate expertise in IT. 


\section{CONCLUSION:}

The study concluded that most of the studied nurses had negative perception regarding aspects of using information technology and most of the studied nurses faced with multiple personal and administrative barriers.

\section{RECOMMENDATION:}

In the light of the results of the contemporary study, the subsequent recommendations were proposed:

I. Providing periodic effective training programs for nurses regarding using of information technology skill in primary care centers.

II. The Ministry of health should be conducting periodic training free of charge for all nurses on how to use information technology especially who were not exposed to computer during their education.

III. Availability of computer to all nurses and make sure all system in the computer work and information technology team should be available.

IV. Fixed and implicit percentage of the total budget of centers should be allocated for the health informatics or health IT department.

\section{REFERENCES:}

Abdrbo, A. A. (2015). Nursing Informatics Competencies Among Nursing Students and

Their Relationship to Patient Safety Competencies: Knowledge, Attitude, and Skills. Computers, informatics, nursing: CIN, 33(11), 509-514.

https://doi.org/10.1097/CIN.0000000000000197.

Abdul Salam, A., Elsegaey, K., \&Khraif, L. (2015). Equivalence of electronic and

paper-based patient-reported outcome measures. Quality of Life Research, 24(8), 1949- 1961

Breimaier, H. E., Halfens, R. JG.,\& Lohrmann, C. (2011). Nurses’ wishes, 
Knowledge, attitudes and perceived barriers on implementing research findings into

practice among graduate nurses in Austria. Journal of Clinical Nursing, 20 (1):1744-1756.

Buabbas, A. J., Al-Shawaf, H. M.,\& Almajran, A. A. (2016). Health Sciences Students' Self-Assessment of Information and Communication Technology Skills and

Attitude toward e-Learning. JMIR Medical Education, 2(1), e9. http://doi.org/10.2196/mededu.5606.

Chan, M. (2019). A cluster analysis to investigating nurse's knowledge and skill regarding the clinical management system. Computers, informatics, nursing: CIN, 25(1), 45-54.

Christiansen, L., Fagerström, C., \& Nilsson, L. (2017). Nurses' Use and Perception of an Information and Communication Technology System for Improving Coordination during Hospital Discharges: A Survey in Swedish Primary Healthcare. Computers, informatics, nursing: CIN, 35(7), 358-363. https://doi.org/10.1097/CIN.0000000000000335.

Ellis, J.R. (2015). Managing and coordinating nursing care. Emerging technologies on

medication errors and adverse drug. Wolters Kluwer.Lippincott Williams\&Willkins. (5) ed Ch 13 pp459-472.

Fajarini, M., Rahayu, S., \& Setiawan, A. (2020). Factors related to doctors' and nurses' perceptions of evidence-based practice and healthcare information access through information and communication technology in Depok City.

Friganovic, A., Jelec, K., \&Sukalic. S. (2016). Nursing and Implementation of Modern

Technology. Retrieved from http://www.signavitae.com/2016/10/nursing-andimplementation-of-modern-technology 
Hasanain, R. (2019). EMRs, features, and implementation experiences throughout the world and in Saudi Arabia, world health report .Geneva http://www.weho.int/wh//en

Hussain, M. (2019). Factors Influencing Nurses' Attitudes towards Information Technology in

Nursing Practice. June 2019, EUROPEAN ACADEMIC RESEARCH Vol. VII, Issue 3/ June 2019.

Irinoye, O. (2018). Nurses' Perception and Barriers to Use of Information Communication Technology in a Teaching Hospital in Nigeria, Obafemi Awolowo University 63 PUBLICATIONS 217 CITATIONS

Jenni, H., Otto, R., \&Olli, R. (2019). Perceptions of nurses about the use of technology

in nursing. Social services, Health and Sports Degree Programme in nursing https://www.ncbi.nlm.nih.gov/books/NBK2686/

Kaye, S. P. (2017). Nurses ${ }^{\text {ee }}$ attitudes toward meaningful use technologies: an integrative review. CIN: Computers, Informatics, Nursing, 35(5), 237-247.

Kleib, M., \& Olson, K. (2015). Evaluation of an informatics educational intervention to

enhance informatics competence among baccalaureate nursing students. Knowledge Management and E-Learning, 7(3), 395-411.

Lin, H. C., Chiou, J. Y., Chen, C. C., \& Yang, C. W. (2016). Understanding the impact of nurses' perception and technological capability on nurses' satisfaction with nursing information system usage: A holistic perspective of alignment. Computers in Human Behavior, 57, 143-152.

Liukko, S., \& Perttula, S. (2017). Opinnäytetyön raportointi. Accessed on 14.02.2019.

Retrieved from https://oppimateriaalit.jamk.fi/raportointiohje/. 
Naylor, K. (2015). Improving healthcare with information technology.UWOMJ/80:1/spring, HEALTH POLICY AND ECONOMICS

Noh, A., Boo,Y., \&Kim, M.(2012). Study of the Difference in Volume of Information in Chief Complaint and Present Illness between Electronic and Paper Medical Records, Health Information Management Journal, vol. 41, 1: pp. 1116. , First Published March 1, 2012

Saad, D. (2014). Evaluation of Electronic Health Records Adoption in Egypt; 3(1), .1131-1134. www.ijera.com

Shin, E. H., Cummings, E., \& Ford, K. (2018). A qualitative study of new graduates" readiness to use nursing informatics. NIS;3(2):24-32.

Woreta, S. A., Kebede, Y., \& Zegeye, D.T. (2013). Knowledge and utilization of information communication technology (ICT) among health science students at the University of Gondar, North Western Ethiopia. doi: 10.1186/1472-6947-13-31 


\section{ادراك الممرضين في استخدام تكنولوجيا المعلومات بمر اكزالرعاية الصحية بمدينة بور سعيد}

رشا محمد بيومى1 ، أ.م.د/ رضا ابر اهيم المو افى²، أ.م.د/ ماجدة على محمد33، د/ عطية مجاهد

$$
\text { مجاهد ابر اهيم4 }
$$

ماجستير تمريض صحة الاسرة و المجتمع، أستاذ مساعد تمريض صحة الاسرة و المجتمع كلية التمريض

جامعة بورسعيد 3,2 ، مدرس تمريض صحة الاسرة و المجتمع كلية التمريض جامعة بورسعيد 4

\section{الخلاصة}

يؤثر التطور التكنولوجي واعتماد التكنولوجيا الجديدة في الرعاية الصحية بشكل كبير على عمل المرضين ، حيث أدى الاستخدام المتزايد لتكنولوجيا المعلومات إلى السعي المستمر لتطوير مهارات وكفاءاة الممرضين ، فمن المتوقع أن تحسن التكنولوجيا جودة الرعاية وتسهل عمل الممرضين في مؤسسات الرعاية الصحية. هدف البحث : صمدت هذه الدر اسة الوصفية لتقييم ادر الك الممرضين في استخدام تكنولوجيا المعلومات بمر اكز الرعاية الصحية بمدينة بور سعيد ـ طرق وادوات البحث تم استخدام أداتين لجمع البيانات: الأداة الأولى عبارة عن استمارة المقابلة الثخصية، أما الأداة الثانية عبارة عن مسح لتقييم معرفة الممرضين المشاركين بتكنولوجيا المعلومات ـ النتائج : أظهرت النتائج ان (84.2\%) من الممرضين الذين شملتهم الدراسة كانوا في خلاف حول الجوانب الإيجابية لاستخدام تكنولوجيا المعلومات ، نصف ممرضين الدراسة (50.5٪) كانوا في خلاف حول الجوانب السلبية لاستخدام تكنولوجيا المعلومات المعلومات.الاستنتاجات :وقد خلصت الدراسة الي أن معظم الممرضين الذين شملتهم الدراسة لديهم إدراك منخفض لاستخدام تكنولوجيا المعلومات.التوصيات : وأوصت الدراسة توافر الحاسوب لجميع الممرضين و التأكد من تو افر جميع النظم في عمل الحاسوب وفريق تكنولوجيا المعلومات. وينبغي

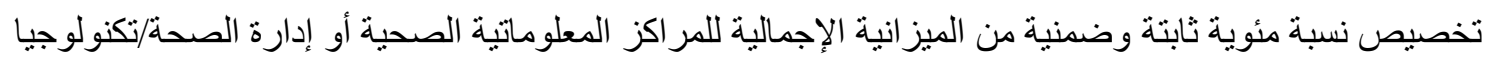

